\title{
Lipoprotein Lipase-mediated Uptake and Degradation of Low Density Lipoproteins by Fibroblasts and Macrophages
}

\author{
Steven C. Rumsey, ${ }^{\star}$ Joseph C. Obunike, ${ }^{\star}$ Yadon Arad, ${ }^{*}$ Richard J. Deckelbaum, ${ }^{*}$ and Ira J. Goldberg ${ }^{\ddagger}$ \\ Departments of *Pediatrics and ${ }^{\ddagger}$ Medicine, Columbia University College of Physicians and Surgeons, New York 10032
}

\begin{abstract}
Lipoprotein lipase (LPL), the rate limiting enzyme for hydrolysis of lipoprotein triglyceride, also mediates nonenzymatic interactions between lipoproteins and heparan sulfate proteoglycans. To determine whether cell surface LPL increases LDL binding to cells, bovine milk LPL was added to upregulated and nonupregulated human fibroblasts along with media containing LDL. LDL binding to cells was increased 2-10-fold, in a dosedependent manner, by the addition of $0.5-10 \mu \mathrm{g} / \mathrm{ml}$ of LPL. The amount of LDL bound to the cells in the presence of LPL far exceeded the capacity for LDL binding via the LDL receptor. Treatment of fibroblasts with heparinase and heparitinase resulted in a $64 \%$ decrease in LPL-mediated LDL binding. Compared to studies performed without LPL, more LDL was internalized and degraded in the presence of $L P L$, but the time course was slower than that of classical lipoprotein receptor mediated pathways. In LDL receptor negative fibroblasts, LPL increased surface bound LDL > 140-fold, intracellular LDL $>$ 40-fold, and LDL degradation > 6-fold. These effects were almost completely inhibited by heparin and anti-LPL monoclonal antibody. LPL also increased the binding and uptake by fibroblasts of apolipoprotein-free triglyceride emulsions; binding was increased $>$ 8-fold and cellular uptake was increased $>$ 40-fold with LPL. LPL increased LDL binding to THP-1 monocytes, and increased LDL uptake (4.5-fold) and LDL degradation (2.5-fold) by THP-1 macrophages. In the absence of added LPL, heparin and anti-LPL monoclonal antibodies decreased LDL degradation by $>\mathbf{4 0} \%$, and triglyceride emulsion uptake by $>\mathbf{5 0} \%$, suggesting that endogenously produced LPL mediated lipid particle uptake and degradation. We conclude that LPL increases lipid and lipoprotein uptake by cells via a pathway not involving the LDL receptor. This pathway may be important for lipid accumulation in LPL synthesizing cells. ( $J$. Clin. Invest. 1992. 90:1504-1512.) Key words: macrophages • atherosclerosis • foam cells • cholesterol • proteoglycans
\end{abstract}

\section{Introduction}

Lipoprotein lipase (LPL) ${ }^{1}$ is the rate limiting enzyme for hydrolysis of triglyceride (TG) in circulating lipoproteins. Aside

Address correspondence to Dr. Ira J. Goldberg, Department of Medicine, Columbia University, 630 West 168th Street, New York, NY 10032.

Received for publication 30 January 1992 and in revised form 7 May 1992.

1. Abbreviations used in this paper: HTGL, hepatic triglyceride lipase; LPL, lipoprotein lipase; LRP, LDL-related protein; TG, triglyceride.

J. Clin. Invest.

(C) The American Society for Clinical Investigation, Inc.

0021-9738/92/10/1504/09 \$2.00

Volume 90, October 1992, 1504-1512 from this enzymatic action as a lipase, LPL may mediate several other biological processes. Uptake of emulsion cholesteryl ester by cultured fibroblasts and rat mesenchymal heart cells was increased after addition of LPL (1), prompting Stein et al. to postulate that LPL can function as a cholesterol transfer protein. Similarly, Traber et al. showed that uptake of vitamin E by fibroblasts was increased in the presence of LPL (2). The LPL-mediated effect on vitamin $E$ uptake was eliminated by heparin which dissociates LPL from cell surfaces. Therefore, these investigators concluded that the presence of LPL protein on the cell surface, rather than LPL enzymatic activity, was required for vitamin E uptake. More recently, Saxena et al. (3) in our laboratory showed that LPL increased LDL retention by subendothelial cell matrix. Because LPL has both lipid and heparin binding sites $(4,5)$, we postulated that LPL can form a bridge between lipoproteins and heparan sulfate proteoglycans.

The classical LDL receptor pathway, and perhaps other receptor mediated pathways, are major mechanisms for cellular internalization of lipoproteins. Recent work, however, has suggested that TG-rich lipoproteins (6), and perhaps other lipidcontaining particles ( 7 ), may be taken up by receptor-independent pathways. Non-receptor mediated uptake mechanisms often involve absorptive endocytosis which, in some cases, follows initial attachment of lipoproteins to cell surfaces. If LPL, bound to cell surface heparan sulfate proteoglycans $(8,9)$, enhances lipoprotein binding to cells, it might then modulate cellular uptake of those particles.

In the current studies we explored whether LPL affected the metabolism of LDL and lipid emulsions by normal fibroblasts, receptor negative fibroblasts, THP-1 monocytes, and THP-1 macrophages. THP-1 monocytes (derived from a human monocytic leukemia), when differentiated, express the LPL gene and secrete LPL $(10,11)$. Our data support the hypothesis that LPL potentiates the binding of LDL and emulsion particles to the cells, thereby increasing their cellular uptake and degradation. This process does not appear to involve classical lipoprotein receptor pathways. Our results suggest that, in certain environments where LPL is present in sufficient concentrations, LPL may enhance cellular uptake of lipoproteins.

\section{Methods}

\section{Low density lipoproteins}

Blood from normolipidemic subjects was collected into Vacutainer tubes (Becton Dickinson, Rutherford, NJ) containing EDTA ( $1 \mathrm{mg} /$ $\mathrm{ml}$ ) and the plasma was separated by centrifugation at 2,000 rpm for $20 \mathrm{~min}$. EDTA ( $1.2 \mathrm{~g} /$ liter $), \mathrm{NaN}_{3}(0.1 \mathrm{~g} /$ liter $)$ and aprotinin $(10,000$ U/liter) (Sigma Chemical Co., St. Louis, MO) were added to the plasma (12) and LDL was isolated by sequential ultracentrifugation $(1.019 \mathrm{~g} / \mathrm{ml}<d<1.063 \mathrm{~g} / \mathrm{ml})(13)$. LDL was radioiodinated using established methods (14) and dialyzed extensively against saline ( 150 $\mathrm{mM} \mathrm{NaCl}, 0.24 \mathrm{mM}$ EDTA, $\mathrm{pH}$ 7.4) before use. Radioactivity was measured using a gamma counter (model 1274; LKB, Gaithersburg, MD). The specific activity of ${ }^{125}$ I-LDL ranged between 100 and 400 $\mathrm{cpm} / \mathrm{ng}$ of LDL protein. Over $99 \%$ of the radioactivity was precipitable 
after a 60 -min incubation with $10 \%(\mathrm{vol} / \mathrm{vol})$ trichloroacetic acid at $4^{\circ} \mathrm{C}$.

\section{Lipoprotein lipase}

LPL was purified from fresh bovine milk using heparin-Sepharose (Pharmacia LKB Biotechnology Inc., Piscataway, NJ) as described by Socorro et al. (15), and stored at $-70^{\circ} \mathrm{C}$. Purified LPL was radioiodinated as described by Saxena et al. (16) and stored in the presence of $1 \%$ BSA (Sigma Chemical Co.) at $-70^{\circ} \mathrm{C}$. Purified LPL showed a single major protein band of $\sim 55 \mathrm{kD}$ when analyzed by SDS-PAGE. The specific activity of labeled LPL ranged between 1,000 and $1,500 \mathrm{cpm} /$ ng. In some experiments a monoclonal antibody was used to block the lipid binding site of LPL. Details of antibody production and specificity have been described previously (17).

\section{Cells}

Fibroblasts. Human (N1) fibroblasts from the foreskin of normal newborns were plated from frozen stock ( 6 th-12th passage) at a density of $2.7 \times 10^{4}$ cells $/ 22-\mathrm{mm}$ well. Using established methods (12), cells were grown for $5 \mathrm{~d}$ in DMEM supplemented with $1 \%$ ( vol/vol) glutamine, $1 \%(\mathrm{vol} / \mathrm{vol})$ penicillin, $1 \%(\mathrm{vol} / \mathrm{vol})$ streptomycin, and $10 \%$ ( vol/vol) calf serum (Gibco Laboratories, Grand Island, NY). To increase the number of LDL receptors on the fibroblast surface, some cells were switched to medium containing $10 \%$ fetal bovine lipoprotein-deficient serum for two additional days before use. These cells are referred to as upregulated fibroblasts. Nonupregulated cells were grown exclusively in serum-containing medium. Lipoprotein-deficient serum was prepared by ultracentrifugation of the serum at $d=1.25 \mathrm{~g} / \mathrm{ml}$ and removal of the lipoprotein-containing supernatant.

LDL receptor-negative fibroblasts (GM2000; Coriell, Camden, $\mathrm{NJ}$ ) were plated at a density of $8 \times 10^{5}$ cells $/ 22-\mathrm{mm}$ well and grown for 10 days in DMEM similar to that described above except that calf serum was replaced with $20 \%$ fetal bovine serum. These cells have $<1 \%$ of the LDL binding capacity of normal fibroblasts.

Monocytes. THP-1 cells were purchased from the American Type Culture Collection (Rockville, MD) and grown in RPMI 1640 (Gibco Laboratories) containing $10 \%$ fetal calf serum as described by Auwerx et al. (18). The medium was changed every three days. Phorbol 12myristate 13 -acetate $\left(1.6 \times 10^{-7} \mathrm{M}\right)$ (Sigma Chemical Co.) was used to differentiate THP-1 cells into macrophages (19) and the cells were grown in RPMI 1640 containing $10 \%$ fetal calf serum, $10^{-8} \mathrm{M}$ insulin, and $10^{-7} \mathrm{M}$ dexamethasone.

\section{Cellular $4^{\circ} \mathrm{C}$ binding of $L D L$ and $L P L$}

Binding of LDL to fibroblasts was measured after a 2.5 -h incubation at $4^{\circ} \mathrm{C}$ in DMEM containing $25 \mathrm{mM}$ Hepes (Sigma Chemical Co.), $1 \%$ $\mathrm{BSA}\left(\mathrm{wt} / \mathrm{vol}\right.$ ), $\mathrm{pH} 7.4$, and $5 \mu \mathrm{g} / \mathrm{ml}{ }^{125} \mathrm{I}-\mathrm{LDL}$. In the majority of experiments, LPL was added to cell media simultaneously with ${ }^{125}$ I-LDL. In a few experiments, LPL was "prebound" to cells during a $2-\mathrm{h}, 4^{\circ} \mathrm{C}$ incubation in DMEM ( $1 \%$ BSA) containing $5 \mu \mathrm{g} / \mathrm{ml} \mathrm{LPL}$. These cells were subsequently washed and ${ }^{125} \mathrm{I}-\mathrm{LDL}$ was added in fresh medium as described above. In either case, after the 2.5 -h incubation, cells were washed five times with PBS ( $2.7 \mathrm{mM} \mathrm{KCl}, 137 \mathrm{mM} \mathrm{NaCl}, 1.5 \mathrm{mM}$ $\mathrm{KH}_{2} \mathrm{PO}_{4}, 8 \mathrm{mM} \mathrm{Na}_{2} \mathrm{HPO}_{4}, 0.2 \mathrm{mM}$ EDTA) $-0.2 \%$ BSA and twice with PBS. The cells were removed from the plates by addition of $0.1 \mathrm{~N}$ $\mathrm{NaOH}$ and total radioactivity bound to the cells was determined. Experiments to study ${ }^{125}$ I-LPL binding to fibroblasts were performed using similar methods to those for LDL binding studies except that bound LPL was assessed by releasing cell surface ${ }^{125} \mathrm{I}-\mathrm{LPL}$ with 100 $\mathrm{U} / \mathrm{ml}$ heparin (Elkins-Sinns, Inc., Cherry Hill, NJ) at $4^{\circ} \mathrm{C} .{ }^{125} \mathrm{I}-\mathrm{LDL}$ and ${ }^{125}$ I-LPL binding to dishes containing only media (nonspecific binding) was $<10 \%$ of that of cell-containing dishes.

LDL binding to THP-1 monocytes was performed using cells in suspension. THP-1 cells cultured in flasks were resuspended in $1 \mathrm{ml}$ of RPMI 1640 medium (1\% BSA) in $2 \mathrm{ml}$ Eppendorf microcentrifuge tubes at a concentration of $3 \times 10^{6} \mathrm{cell} / \mathrm{ml}$. ${ }^{125} \mathrm{I}-\mathrm{LDL}(5 \mu \mathrm{g} / \mathrm{ml})$ and unlabeled LPL $(10 \mu \mathrm{g} / \mathrm{ml})$ were added and the cells were incubated for
$2 \mathrm{~h}$ at $4^{\circ} \mathrm{C}$ on a platform rocker. The cells were then pelleted, resuspended in fresh medium, transferred to new Eppendorf tubes, and washed twice with cold PBS containing $0.2 \%$ BSA and once with PBS. LDL radioactivity associated with the cell surface via LPL was determined as the amount of radioactivity released from the cells after incubation for $30 \mathrm{~min}$ at $4^{\circ} \mathrm{C}$ in PBS containing $100 \mathrm{U} / \mathrm{ml}$ of heparin.

\section{Cellular binding, uptake, and degradation of $L D L$}

Cell surface bound, intracellular, and degraded LDL were assessed using nonupregulated fibroblasts. ${ }^{125} \mathrm{I}-\mathrm{LDL}(5 \mu \mathrm{g} / \mathrm{ml})$ was bound to the cell surface in the presence or absence of $\operatorname{LPL}(10 \mu \mathrm{g} / \mathrm{ml})$ at $4^{\circ} \mathrm{C}$ for 2.5 $h$. The medium was removed and the cells washed three times with PBS- $0.2 \%$ BSA to remove unbound LDL. Cells were then warmed to $37^{\circ} \mathrm{C}$ and cell surface, intracellular, and degraded LDL were determined over time. Cell-surface LDL anchored by LPL was assessed by incubating the cells for $30 \mathrm{~min}$ at $4^{\circ} \mathrm{C}$ with PBS containing $100 \mathrm{U} / \mathrm{ml}$ heparin. Cells were subsequently incubated $1 \mathrm{~h}$ at $4^{\circ} \mathrm{C}$ with $1,400 \mathrm{U} /$ $\mathrm{ml}$ of heparin to remove any remaining LPL or LDL from the surface, washed once with PBS containing 0.2\% BSA and twice with PBS, and dissolved in $0.1 \mathrm{~N} \mathrm{NaOH}$. This second heparin wash led to minimal additional LDL release. The radioactivity in the $\mathrm{NaOH}$ fraction represented the amount of intracellular LDL. LDL degradation was determined as the amount of trichloroacetic acid soluble, noniodine, radioactivity in the medium (12). Parallel incubations in cell-free wells were performed to control for non-cell mediated LDL degradation.

Surface binding, uptake, and degradation of LDL were also studied in receptor-negative fibroblasts and THP-1 macrophages. Cells were incubated at $37^{\circ} \mathrm{C}$ for $18 \mathrm{~h}$ with ${ }^{125} \mathrm{I}-\mathrm{LDL}(10 \mu \mathrm{g} / \mathrm{ml}$ for fibroblasts, 5 $\mu \mathrm{g} / \mathrm{ml}$ for macrophages) in $22-\mathrm{mm}$ tissue culture plates, the LDL-containing media was removed, and cells were washed with $4^{\circ} \mathrm{C}$ buffers as described earlier. Cell surface (heparin-releasable), intracellular, and degraded LDL were determined as described above in the presence or absence of heparin $(10 \mathrm{U} / \mathrm{ml})$, anti-LPL monoclonal antibody (100 $\mu \mathrm{g} / \mathrm{ml}$ ), or nonspecific anti-mouse IgG.

\section{Lipid emulsions}

$50 \mathrm{mg}$ of triolein (Nu-Check, Elysian, $\mathrm{MN}$ ) was added to $50 \mathrm{mg}$ of egg yolk phosphatidylcholine (Avanti Polar Lipids, Inc., Alabaster, AL) and the organic solvents completely evaporated under $\mathrm{N}_{2} .50 \mu \mathrm{Ci}$ of $\left[{ }^{3} \mathrm{H}\right]$ cholesteryl hexadecyl ether (New England Nuclear, Boston, MA) was added as a nondegradable neutral lipid marker. The dry lipids were resuspended in saline at $60^{\circ} \mathrm{C}$ with added sucrose $(1 \mathrm{~g} / 10 \mathrm{ml})$ and sonicated for $1 \mathrm{~h}$ at $55^{\circ} \mathrm{C}$ at $140 \mathrm{~W}$ under a stream of nitrogen using a Branson sonifier (model 450; Branson Ultrasonics Corp., Danbury, CT). After sonication, the solution was dialyzed overnight to remove sucrose, centrifuged for $20 \mathrm{~min}$ at $40,000 \mathrm{rpm}$, and the opaque middle fraction containing small emulsion particles removed ( free of phospholipid liposomes, which because of their trapped sucrose sink to the bottom of the infranate). This fraction was then spun at $28,000 \mathrm{rpm}$ for $15 \mathrm{~h}$, collected, and analyzed for TG and phospholipid content.

\section{Cellular binding and uptake of $T G$ emulsions}

Nonupregulated fibroblasts were incubated for 5 or $22 \mathrm{~h}$ at $37^{\circ} \mathrm{C}$ with TG emulsions ( $200 \mu \mathrm{g} / \mathrm{ml} \mathrm{TG} / \mathrm{ml}$, TG/phospholipid ratio of 2.38$)$, containing a nondegradable marker, $\left[{ }^{3} \mathrm{H}\right]$ cholesteryl ether $(510 \mathrm{cpm} /$ $\mu \mathrm{g}$ TG) with or without LPL $(10 \mu \mathrm{g} / \mathrm{ml})$ and heparin $(10 \mathrm{U} / \mathrm{ml})$. After incubation, the cell media was removed and analyzed for TG hydrolysis and the cells were washed and treated as described above for LDL studies. Bound emulsion was considered the radioactivity released by a 30-min incubation with PBS containing heparin ( $100 \mathrm{U} /$ $\mathrm{ml}$ ). Uptake was considered the amount of radioactivity remaining with the cells after an additional 60-min incubation with PBS containing heparin $(1,400 \mathrm{U} / \mathrm{ml})$ and further washing with PBS-BSA and PBS as described earlier.

THP-1 macrophages were incubated for $18 \mathrm{~h}$ at $37^{\circ} \mathrm{C}$ with TG emulsion $(200 \mu \mathrm{g} / \mathrm{ml}, \mathrm{TG} /$ phospholipid ratio of 1.71$)$ containing the $\left[{ }^{3} \mathrm{H}\right]$ cholesteryl ether $(1,021 \mathrm{cpm} / \mu \mathrm{g}$ TG $)$. The cells were scraped 
from cell plates using rubber policemen and washed in microcentrifuge tubes. Emulsion binding and uptake were determined as described above.

\section{Biochemical analyses}

LDL, LPL, and cell protein were measured using the method of Lowry (20). TG was analyzed using enzymatic kit No. 877557 (Boehringer Mannheim Corp., Indianapolis, IN), and free fatty acids were analyzed using NEFA-C enzymatic kit No. 990-75401 (Wako, Dallas, TX). Lipid emulsion phospholipid was analyzed using the Bartlett assay (21). THP-1 LPL activity was assayed using radiolabeled triolein emulsified with phosphatidylcholine (22).

\section{Results}

LPL-mediated LDL binding to fibroblasts. Fig. $1 A$ shows the effects of increasing concentrations of LPL on LDL binding to fibroblasts. Both upregulated and nonupregulated fibroblasts were studied to test whether LDL receptors were involved in LPL-mediated effects. Under control conditions (no LPL) $44.0 \pm 6.7 \mathrm{ng}$ of $\mathrm{LDL} / \mathrm{mg}$ cell protein bound to the nonupregulated fibroblast and $162.0 \pm 13.0 \mathrm{ng}$ of $\mathrm{LDL} / \mathrm{mg}$ cell protein bound to upregulated cells, reflecting the significantly larger number of receptors on upregulated cells. With increasing LPL concentrations LDL binding increased markedly. As little as 1 $\mu \mathrm{g} / \mathrm{ml}$ of LPL increased LDL binding to upregulated cells by $250 \%$; LDL binding to nonupregulated cells increased $>700 \%$. Using $10 \mu \mathrm{g} / \mathrm{ml} \mathrm{LPL}$, LDL binding increased to $>3,000 \mathrm{ng}$ of $\mathrm{LDL} / \mathrm{mg}$ cell protein in both upregulated and nonupregulated cells. It should be noted that in the absence of LPL, maximum

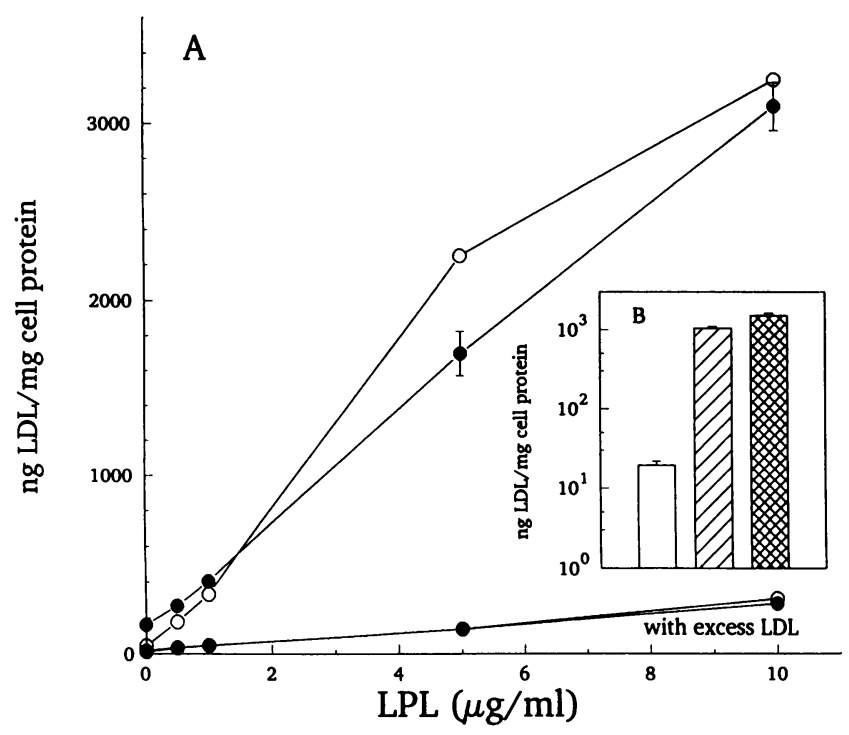

Figure 1. LPL-mediated binding of ${ }^{125} \mathrm{I}-\mathrm{LDL}(5 \mu \mathrm{g} / \mathrm{ml})$ to fibroblasts. $(A)$ Upregulated fibroblasts $(\bullet)$ and nonupregulated fibroblasts (O) were incubated at $4^{\circ} \mathrm{C}$ with $\mathrm{LDL}$ and increasing concentrations of LPL. Nonspecific binding was assessed by addition of a 30-fold excess of unlabeled LDL. Shown are the means \pm SD of experiments performed in triplicate. Some SD bars are smaller than the symbol size. (B) Inset. Comparison of LDL binding to fibroblasts with prebound LPL (四) and LPL in solution ( $\square$ ). Cells were preincubated with 5 $\mu \mathrm{g} / \mathrm{ml}$ of LPL before addition of medium containing LDL, or the LPL and LDL were added simultaneously. Control cells ( $\square$ ) were incubated with LDL only. Data, mean $\pm \mathrm{SD}$, are displayed on a logarithmic scale. $4^{\circ} \mathrm{C}$ binding of LDL to upregulated human skin fibroblasts is $100-200 \mathrm{ng} \mathrm{LDL} / \mathrm{mg}$ cell protein (23). The addition of a 30 fold excess of nonradiolabeled LDL decreased ${ }^{125} \mathrm{I}$-LDL binding by $\sim 90 \%$ at all doses. At LPL concentrations $<1.5 \mu \mathrm{g} / \mathrm{ml}$, LDL binding to upregulated cells exceeded the binding to nonupregulated cells, reflecting the contribution of LDL receptors. At LPL concentrations $>1.5 \mu \mathrm{g} / \mathrm{ml}$ (corresponding to $>400$ ng LDL bound/mg cell protein), LDL binding to upregulated and nonupregulated cells was similar. This, and the observation that LPL-mediated LDL binding far exceeded saturable LDL binding to LDL receptors, strongly suggested that LPLmediated LDL binding was not via the LDL receptor.

We next tested whether LPL prebound to fibroblasts would have the same effect on LDL binding as LPL in solution. First, we assessed whether LPL would bind to the fibroblast surface. Using up to $30 \mu \mathrm{g}$ of ${ }^{125} \mathrm{I}-\mathrm{LPL}, \sim 5-10 \%$ of the added LPL bound to the cell surface and was released by heparin-containing buffers. LPL binding was maximal after $60 \mathrm{~min}$ of incubation at $4^{\circ} \mathrm{C}$ (data not shown). Thus, LPL binds to a heparinsensitive site on the surface of cultured fibroblasts.

The ability of cell surface bound LPL to enhance LDL binding was then assessed. Nonupregulated fibroblasts were incubated with LPL $(5 \mu \mathrm{g} / \mathrm{ml})$ for $2 \mathrm{~h}$ at $4^{\circ} \mathrm{C}$ and the medium was then replaced with LPL-free medium containing ${ }^{125} \mathrm{I}-\mathrm{LDL}$ (prebound). Other cells were incubated with medium containing both LPL and LDL ( simultaneous addition ). LDL binding to fibroblasts increased dramatically with either method of LPL addition. Compared to control cells incubated without LPL, cells with prebound LPL bound > 50-fold more LDL (Fig. $1 B$ ). Cells coincubated with the same amount of LPL and ${ }^{125} \mathrm{I}$-LDL bound $>75$-fold more LDL than control cells. The somewhat lesser effect with prebound LPL may be the result of less LPL on the cell surface due to the additional washing step and dissociation of bound LPL into fresh, LPLfree media. Nonetheless, prebound LPL also markedly increased LDL binding to the fibroblasts.

Internalization and degradation of cell surface bound $L D L$. We next questioned whether the LDL that binds to fibroblasts via an LPL-mediated process could be internalized and degraded. ${ }^{125} \mathrm{I}-\mathrm{LDL}$ was first bound to fibroblasts at $4^{\circ} \mathrm{C}$ and then the cells were washed and incubated with fresh medium at $37^{\circ} \mathrm{C}$. Cell surface, intracellular, and degraded LDL were assessed in wells incubated for different lengths of time up to $24 \mathrm{~h}$ (Fig. 2). Cell surface LDL (open circles) decreased $\sim 30 \%$ in the first hour to $384 \mathrm{ng}$ of LDL/mg cell protein. After $6 \mathrm{~h}$, $<20 \%$ of the LDL remained on the cell surface. During the same time period, intracellular LDL increased (closed circles). Maximal intracellular LDL, $289.4 \pm 11.6 \mathrm{ng} / \mathrm{mg}$ cell protein, was seen at $6 \mathrm{~h}$. Non-TCA-precipitable radioactivity, representing LDL protein degradation (triangles), increased linearly for the first $6 \mathrm{~h}$. A smaller increase in degradation occurred between 12 and $24 \mathrm{~h}$. In contrast, in experiments without LPL (Fig. $2 \mathrm{~B}$ ), cell surface LDL decreased more rapidly (>80 decrease in $1 \mathrm{~h}$ ) and LDL uptake was faster, peaking at $3.7 \pm 0.4$ $\mathrm{ng} / \mathrm{mg}$ cell protein by $1 \mathrm{~h}$. LDL degradation was also much more rapid. $50 \%$ of LDL was degraded by $1 \mathrm{~h}$ compared to only $10 \%$ degraded by $1 \mathrm{~h}$ in the presence of LPL. Thus, LPL markedly increased the amount of LDL internalized and degraded by fibroblasts, but this process was much slower than LDL uptake and degradation via the LDL receptor (21), suggesting that a different metabolic process was involved. 


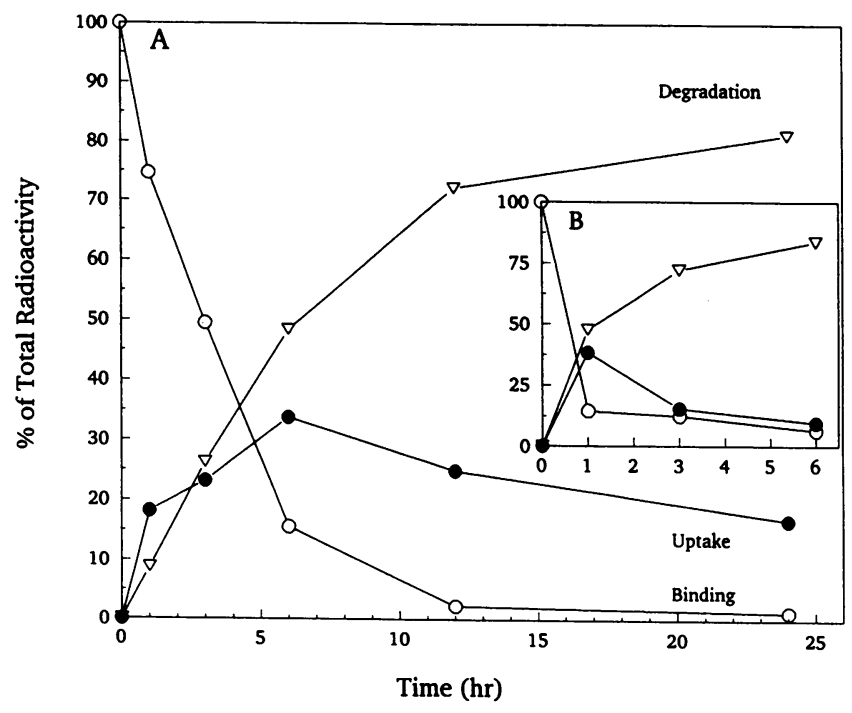

Figure 2. Time course of LPL-mediated ${ }^{125} \mathrm{I}-\mathrm{LDL}(5 \mu \mathrm{g} / \mathrm{ml})$ metabolism in nonupregulated fibroblasts. $(A)$ Fibroblasts were incubated for $2.5 \mathrm{~h}$ at $4^{\circ} \mathrm{C}$ in medium containing LPL $(10 \mu \mathrm{g} / \mathrm{ml})$ and LDL. Non-cell associated LPL and LDL were removed by repeated washes and the cells were then incubated at $37^{\circ} \mathrm{C}$ in fresh medium for various lengths of time. Cell surface $(0)$, intracellular $(\bullet)$ and degraded LDL $(\nabla)$ were determined. Data are expressed as the percentage of total radioactivity in each dish at each time point, excluding nondegraded LDL in the media. $(B)$ Inset. Time course of cell surface, intracellular, and degraded LDL in the absence of LPL. Methods and symbols are as described in $A$.

Effects of heparitinase/heparinase and chondroitinase $A B C$ on LPL-mediated LDL binding to fibroblasts. To test whether increased LDL binding induced by LPL required heparan sulfate proteoglycans, nonupregulated fibroblasts were pretreated at $37^{\circ} \mathrm{C}$ for $1 \mathrm{~h}$ with either heparitinase $(2.5 \mathrm{U} / \mathrm{ml})$ and heparinase $(2.5 \mathrm{U} / \mathrm{ml})$ or with chondroitinase $\mathrm{ABC}(5$

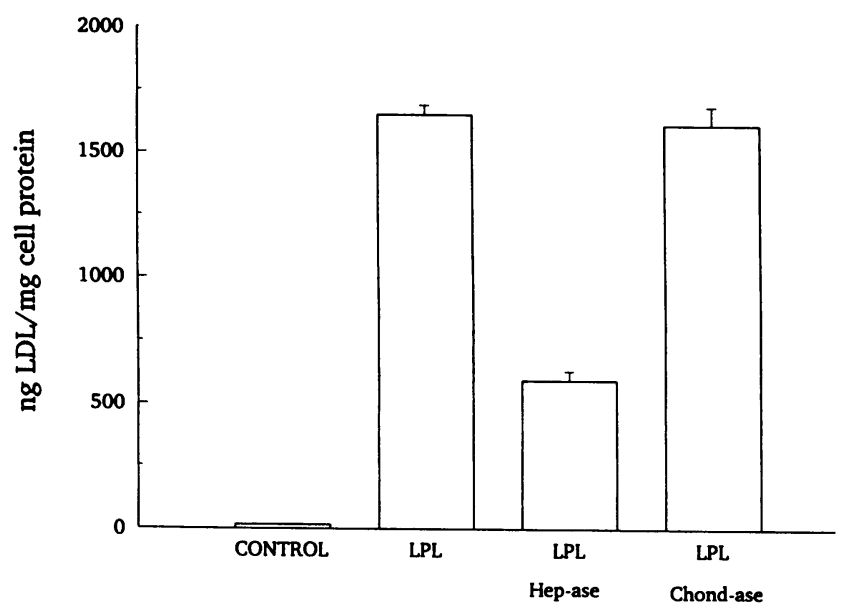

Figure 3. Effects of heparitinase and heparinase or chondroitinase ABC on LPL-mediated binding of LDL. Nonupregulated fibroblasts were first treated for $1 \mathrm{~h}$ at $37^{\circ} \mathrm{C}$ with no enzyme, a combination of heparinase and heparitinase (hep-ase) $(2.5 \mathrm{U} / \mathrm{ml}$ of each), or chondroitin ABCase (chond-ase) $(2.5 \mathrm{U} / \mathrm{ml})$. Afterwards, cells were washed, cooled to $4^{\circ} \mathrm{C}$, and ${ }^{125} \mathrm{I}-\mathrm{LDL}$ binding to the cells was assessed under control conditions and in the presence of LPL $(10 \mu \mathrm{g} / \mathrm{ml})$. Shown are the means \pm SD of triplicate dishes.
U/ml; Seikagaku America Inc., Rockville, MD). Enzyme activities (units) are given as $0.1 \mu \mathrm{mol} / \mathrm{h}$. The cells were then cooled to $4^{\circ} \mathrm{C}$ and ${ }^{125} \mathrm{I}-\mathrm{LDL}(5 \mu \mathrm{g} / \mathrm{ml})$ were allowed to bind to the cells in the presence or absence of LPL. LPL dramatically increased LDL surface binding by $>100$-fold. Cells pretreated with the heparitinase/heparinase had $64 \%$ less LPL-mediated LDL binding to the cell surface; the chondroitinase treatment had no effect (Fig. 3). Therefore, most of the LPL-mediated LDL binding to the cells was via a heparinase/heparitinasesensitive mechanism.

LPL-mediated LDL metabolism by $L D L$ receptor negative fibroblasts. To further establish whether or not the LDL receptor played a role in the enhanced metabolism of LDL in the presence of LPL, we performed experiments with receptor-negative fibroblasts. The cells were incubated with ${ }^{125}$ I-LDL ( 10 $\mu \mathrm{g} / \mathrm{ml}$ ) alone, or along with LPL, with or without heparin or anti-LPL monoclonal antibody. As shown in Fig. 4, LPL dramatically increased cell surface, intracellular, and degraded $\mathrm{LDL}$ after an $18-\mathrm{h}$ incubation at $37^{\circ} \mathrm{C}$ (note that some of the data are displayed on a logarithmic scale). Both heparin and anti-LPL monoclonal antibody almost completely reversed the LPL-mediated increases. In $4^{\circ} \mathrm{C}$ experiments, LPL also in-
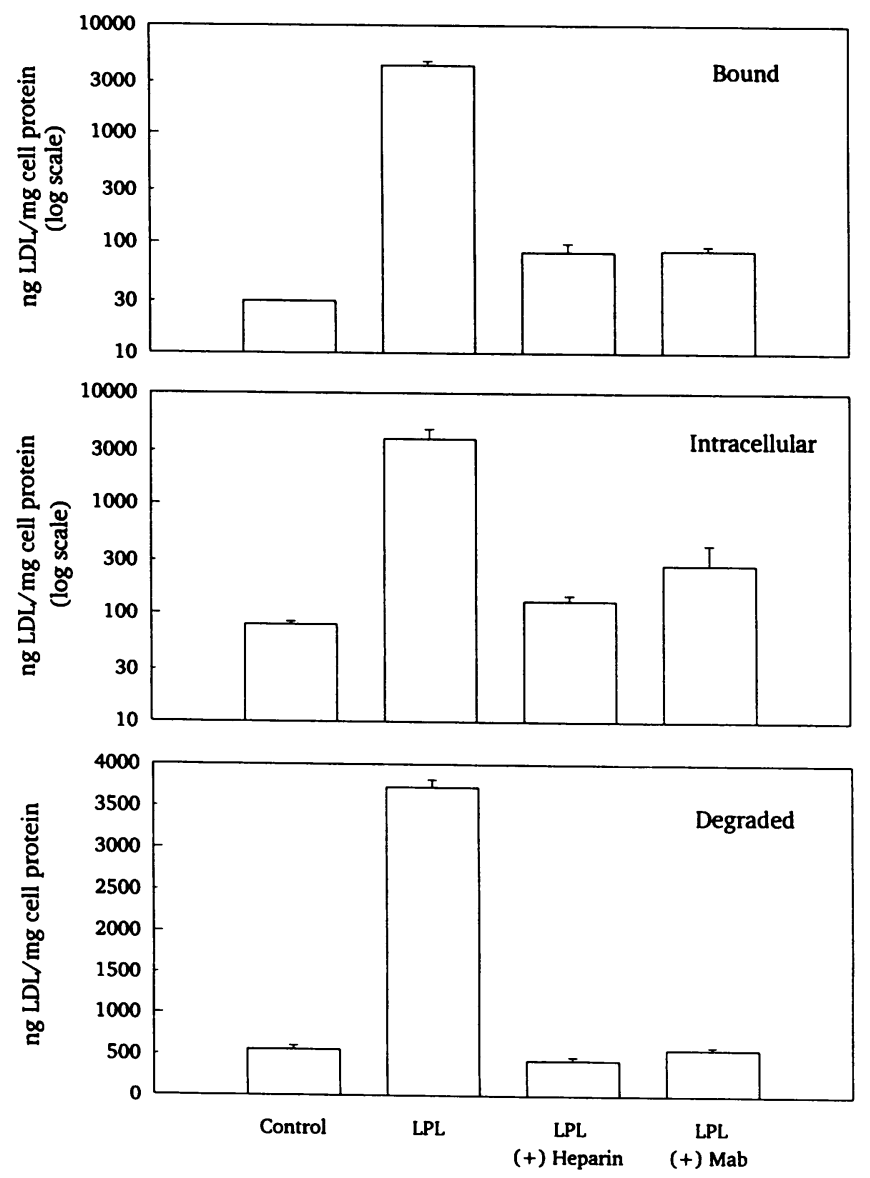

Figure 4. LDL metabolism in LDL receptor negative fibroblasts. ${ }^{125} \mathrm{I}$ $\mathrm{LDL}(10 \mu \mathrm{g} / \mathrm{ml})$ were incubated for $18 \mathrm{~h}$ at $37^{\circ} \mathrm{C}$ with LDL receptor-negative fibroblasts in control medium or medium containing LPL $(10 \mu \mathrm{g} / \mathrm{ml})$ alone, LPL and heparin $(10 \mathrm{U} / \mathrm{ml})$, or LPL and anti-LPL antibody $(100 \mu \mathrm{g} / \mathrm{ml})$. Shown are cell surface bound, intracellular, and degraded $\mathrm{LDL}$, mean \pm SD of triplicate determinations. 
creased LDL binding to the cell surface by $>200$-fold (data not shown). Thus, the LPL effects did not require the LDL receptor.

Binding and uptake of lipid emulsions. To test if the LPL effect required apolipoproteins, we studied whether LPL could also increase the binding and uptake of apolipoprotein-free lipid emulsion particles. Fibroblasts were incubated for 5 or 22 h at $37^{\circ} \mathrm{C}$ with $\mathrm{TG}$ emulsion containing a nondegradable marker $\left[{ }^{3} \mathrm{H}\right]$ cholesteryl ether $(510 \mathrm{cpm} / \mu \mathrm{g} \mathrm{TG})$, with or without LPL and heparin. LPL markedly increased cell surface binding and uptake (expressed on a log scale) of emulsion particles (Fig. 5). LPL-mediated emulsion binding was signifcantly greater at $5 \mathrm{~h}(13,999 \pm 374 \mathrm{cpm} / \mathrm{mg}$ cell protein $)$ compared with $22 \mathrm{~h}(5,534 \pm 1,668 \mathrm{cpm} / \mathrm{mg}$ cell protein, $P$ $<0.002)$. The opposite was true for cellular uptake which was less at $5 \mathrm{~h}(27,951 \pm 379 \mathrm{cpm} / \mathrm{mg}$ cell protein $)$ than at $22 \mathrm{~h}$ $(89,362 \pm 13,536 \mathrm{cpm} / \mathrm{mg}$ cell protein, $P<0.002)$. This suggested that, similar to studies with LDL, LPL-mediated uptake of emulsion particles was a relatively slow process. Heparin ( 10 $\mathrm{U} / \mathrm{ml}$ ) completely inhibited the LPL-mediated uptake and binding of $\left[{ }^{3} \mathrm{H}\right]$ cholesteryl ether. This occurred despite a similar amount of TG hydrolysis, as assessed by measurements of TG and free fatty acids, in dishes with LPL with or without heparin. Therefore, (a) LPL increased cellular uptake of emul-
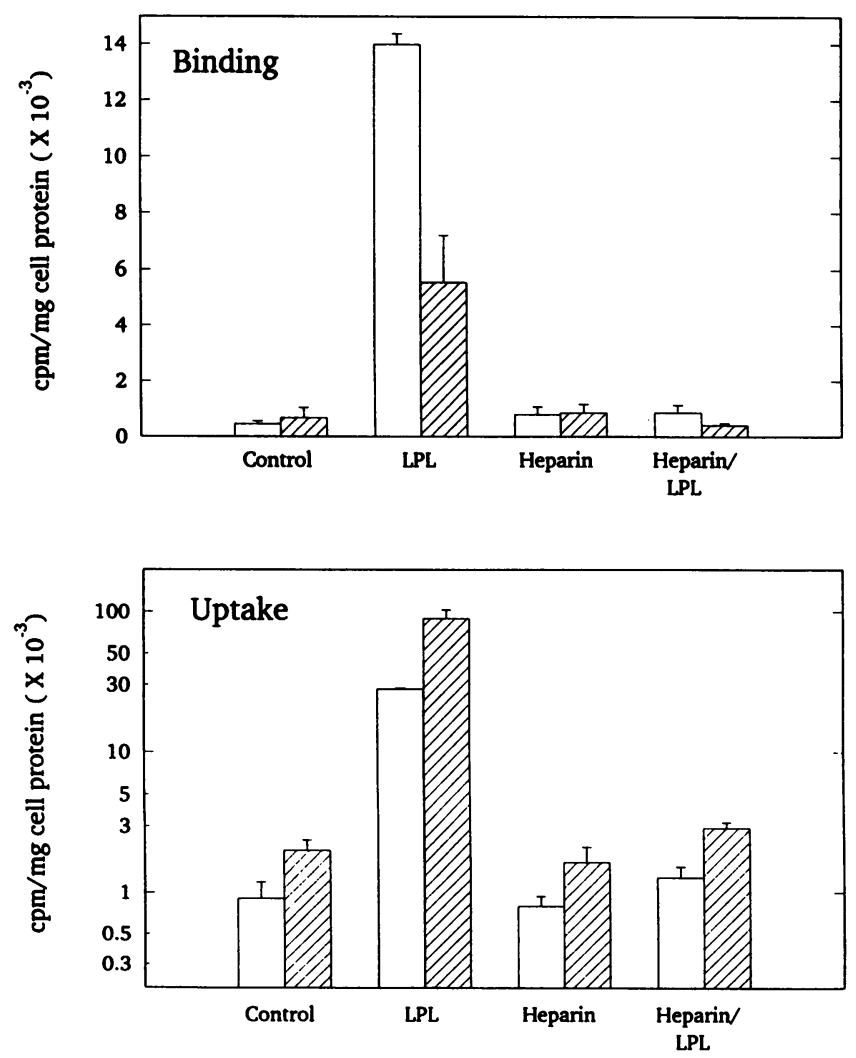

Figure 5. LPL-mediated binding and uptake of triglyceride emulsion by fibroblasts. Cells were incubated for $5(\square)$ or $22(0) \mathrm{h}$ at $37^{\circ} \mathrm{C}$ in medium containing TG emulsion particles labeled with $\left[{ }^{3} \mathrm{H}\right]-$ cholesteryl ether $(510 \mathrm{cpm} / \mu \mathrm{g} \mathrm{TG})$. LPL $(10 \mu \mathrm{g} / \mathrm{ml})$, heparin $(100$ $\mathrm{U} / \mathrm{ml}$ ) or both were added to the media. Shown are the amounts (mean \pm SD) of radioactivity bound to the cell surfaces (Binding) and internalized (Uptake) by the cells.

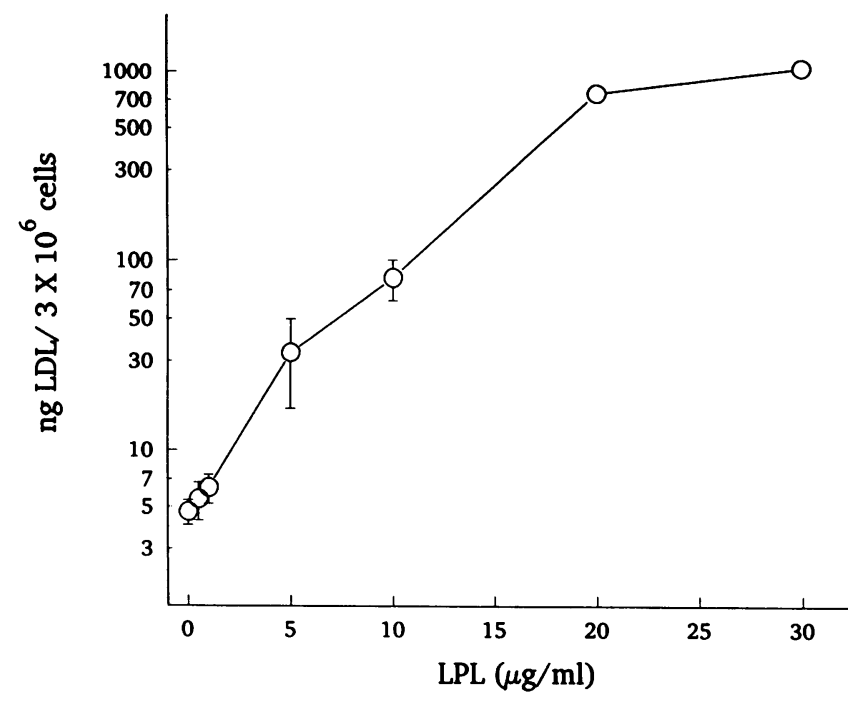

Figure 6. LPL-mediated binding of ${ }^{125} \mathrm{I}-\mathrm{LDL}(5 \mu \mathrm{g} / \mathrm{ml})$ to THP-1 monocytes. Aliquots of $3 \times 10^{6}$ cells were incubated for $2 \mathrm{~h}$ at $4^{\circ} \mathrm{C}$ with LDL and increasing concentrations of LPL. The amounts (mean \pm SD of triplicates) of cell bound radioactivity, released with heparin $(100 \mathrm{U} / \mathrm{ml})$, are shown.

sion particles, but this was not related to lipase activity; and $(b)$ apolipoproteins were not required for LPL-mediated lipid/lipoprotein uptake by cells.

LPL-mediated LDL binding by THP-1 cells. To test whether LPL also increased LDL binding to monocytes, we assessed the binding of ${ }^{125} \mathrm{I}-\mathrm{LDL}$ to THP-1 monocytes in the presence or absence of LPL. As shown in Fig. 6, addition of LPL led to a dramatic, dose-dependent, increase in cell surface LDL binding at $4^{\circ} \mathrm{C}$. Note that the data are graphed on a logarithmic scale. Without LPL, $4.7 \pm 0.7 \mathrm{ng}$ of $\mathrm{LDL}$ was released from $3 \times 10^{6}$ cells by heparin treatment. $5 \mu \mathrm{g} / \mathrm{ml}$ of LPL increased LDL binding to $33.3 \pm 16.6 \mathrm{ng}$ of LDL per $3 \times 10^{6}$ cells; $30 \mu \mathrm{g} / \mathrm{ml}$ of LPL increased binding to $1,053 \pm 107 \mathrm{ng}$ of $\mathrm{LDL}$ per $3 \times 10^{6}$ cells.

Metabolism of LDL and TG emulsion by THP-1 macrophages in the presence of added $L P L$. We next studied whether LPL altered LDL uptake by differentiated THP-1 macrophages. LPL ( $10 \mu \mathrm{g} / \mathrm{ml})$ was added to ${ }^{125} \mathrm{I}$-LDL-containing media and cell surface, intracellular, and degraded LDL were assessed after an $18-\mathrm{h}, 37^{\circ} \mathrm{C}$ incubation. Addition of LPL resulted in the following effects: $(a)$ LDL binding increased from 20.6 to $201.7 \mathrm{ng} / \mathrm{mg}$ cell protein $(P<0.0006)$; $(b)$ intracellular LDL increased from 134.1 to $600.7 \mathrm{ng} / \mathrm{mg}$ cell protein $(P$ $<0.0002)$; and (c) LDL degradation increased from 450 to $1154 \mathrm{ng} / \mathrm{mg}$ cell protein $(P<0.002)$ (Fig. $7 A$ ). Anti-LPL monoclonal antibody $(100 \mu \mathrm{g} / \mathrm{ml})$ reduced the LPL-mediated cell surface LDL binding by $61 \%(P<0.005)$, internalization by $68 \%(P<0.0001)$, and degradation by $87 \%(P<0.001)$. Therefore, even in THP-1 macrophages, additional LPL increased LDL metabolism.

The effect of added LPL on cellular uptake of TG emulsion particles is shown in Fig. $7 \mathrm{~B}$. Cells were incubated with TG emulsion labeled with $\left[{ }^{3} \mathrm{H}\right]$ cholesteryl ether $(1,021 \mathrm{cpm} / \mu \mathrm{g}$ TG) for $18 \mathrm{~h}$. Addition of LPL resulted in a 55\% increase in emulsion uptake $(P<0.001)$, which was completely abolished 

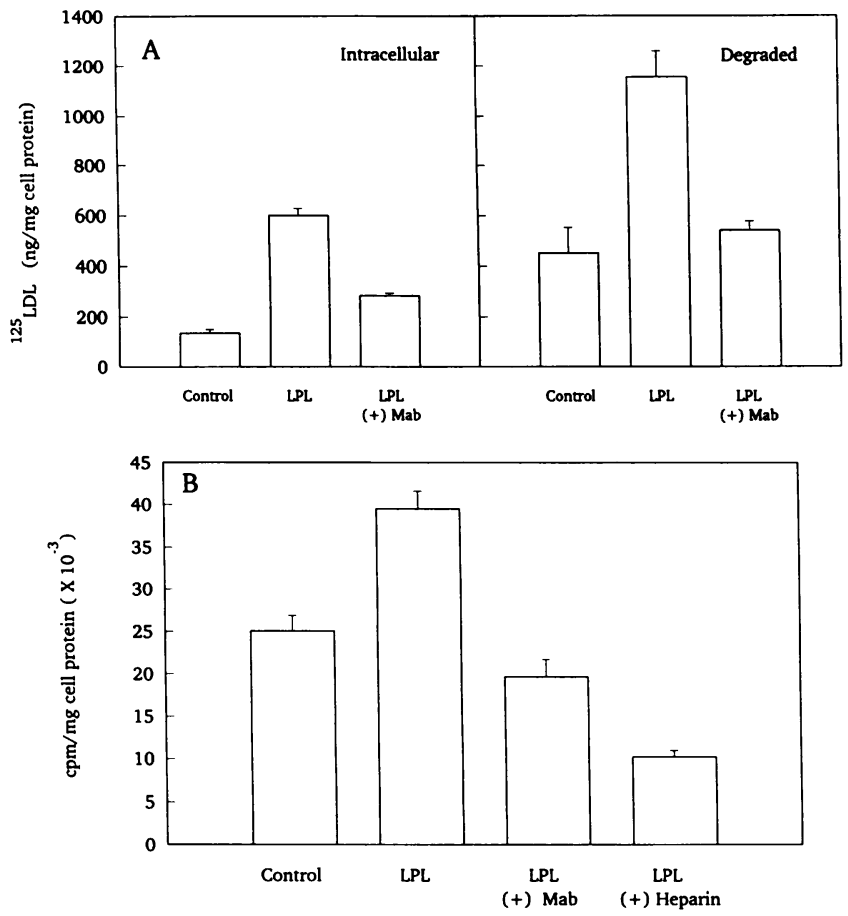

Figure 7. Effect of added LPL on LDL and TG emulsion metabolism in THP-1 macrophages. $(A)$ THP-1 macrophages were incubated for $18 \mathrm{~h}$ at $37^{\circ} \mathrm{C}$ in media containing ${ }^{125} \mathrm{I}-\mathrm{LDL}(5 \mu \mathrm{g} / \mathrm{ml})$ with the addition of LPL $(10 \mu \mathrm{g} / \mathrm{ml})$ with or without monoclonal anti-LPL antibody $(M a b)$. After the incubation the media was removed to determine TCA-soluble radioactivity (Degraded), and cells were washed as described in Methods and dissolved in $0.1 \mathrm{~N} \mathrm{NaOH}$ (Intracellular). (Mean \pm SD of triplicates). (B) Macrophages were incubated for 18 $\mathrm{h}$ with TG emulsion $(200 \mu \mathrm{g} / \mathrm{ml}$, containing a nondegradable marker, $\left[{ }^{3} \mathrm{H}\right]$ cholesterol-ether $(510 \mathrm{cpm} / \mu \mathrm{g} \mathrm{TG})$. As above, LPL $(10 \mu \mathrm{g} / \mathrm{ml})$ was added with or without monoclonal anti-LPL antibody ( $M a b)$ or heparin $(10 \mathrm{U} / \mathrm{ml})$ and intracellular radioactivity was determined. (Mean \pm SD of triplicates).

by the addition of heparin or anti-LPL monoclonal antibody. Nonspecific (control) IgG had no inhibitory effect.

Role of endogenous LPL in THP-1 macrophages. Since THP-1 macrophages secrete LPL, we asked whether LPL endogenously synthesized by macrophages modulated LDL and TG emulsion metabolism. To explore this, heparin $(10 \mathrm{U} / \mathrm{ml})$ was used to release endogenously produced LPL from the cell surface and anti-LPL monoclonal antibodies were used to inhibit LPL interaction with lipoproteins (17). As shown in Fig. $8 \mathrm{~A}$, during an 18-h incubation, heparin decreased LDL degradation by $41 \%(P<0.05)$ and anti-LPL antibody decreased degradation by $49 \%(P<0.02)$. Intracellular LDL was decreased comparable amounts. In an 18-h incubation with TG emulsion particles, heparin also decreased particle uptake by $59 \%(P<0.0001)$ and anti-LPL monoclonal antibody decreased particle uptake by $69 \%(P<0.0001)$. Thus, our data suggest that LPL synthesized by THP-1 macrophages was responsible for at least $40-50 \%$ of LDL uptake and degradation, and $60-70 \%$ of TG emulsion uptake by these cells.

\section{Discussion}

Our data demonstrate that LPL dramatically increased LDL metabolism by fibroblasts and THP-1 cells. A number of experi- mental observations support the hypothesis that this process does not involve the LDL receptor. (a) LPL-mediated LDL binding to upregulated and nonupregulated cells was similar. (b) The amount of LDL bound via a LPL-mediated mechanism greatly exceeded maximal binding by the LDL receptor. (c) The uptake and degradation of LDL bound in the presence of LPL were much slower than uptake and degradation via LDL receptors. $(d)$ LPL-mediated LDL binding was susceptible to heparitinase/heparinase, suggesting that increased LDL binding to the fibroblast cell was mediated by surface heparan sulfate proteoglycans. (e) LPL increased LDL metabolism by LDL receptor negative fibroblasts. $(f)$ LPL increased cellular uptake of non-apolipoprotein-containing lipid emulsions. These emulsion particles are not ligands for either the LDL receptor or other lipoprotein receptors. Furthermore, anti-LPL antibody which interferes with LPL interaction with lipoproteins (17) also inhibited LPL-mediated uptake and degradation. Therefore, LPL mediates the cellular binding of LDL and lipid emulsion particles by a previously undescribed mechanism requiring the interaction of LPL with lipoproteins and heparan sulfate proteoglycans.

Three other processes, all of which augment lipoprotein uptake by cells, are unlikely to be responsible for our results. First, LPL-mediated LDL uptake by fibroblasts and macrophages most likely did not involve aggregation of LDL molecules. Although incubation of LDL with phospholipase $\mathrm{C}$ aggregates LDL and increases LDL uptake (24), bovine milk
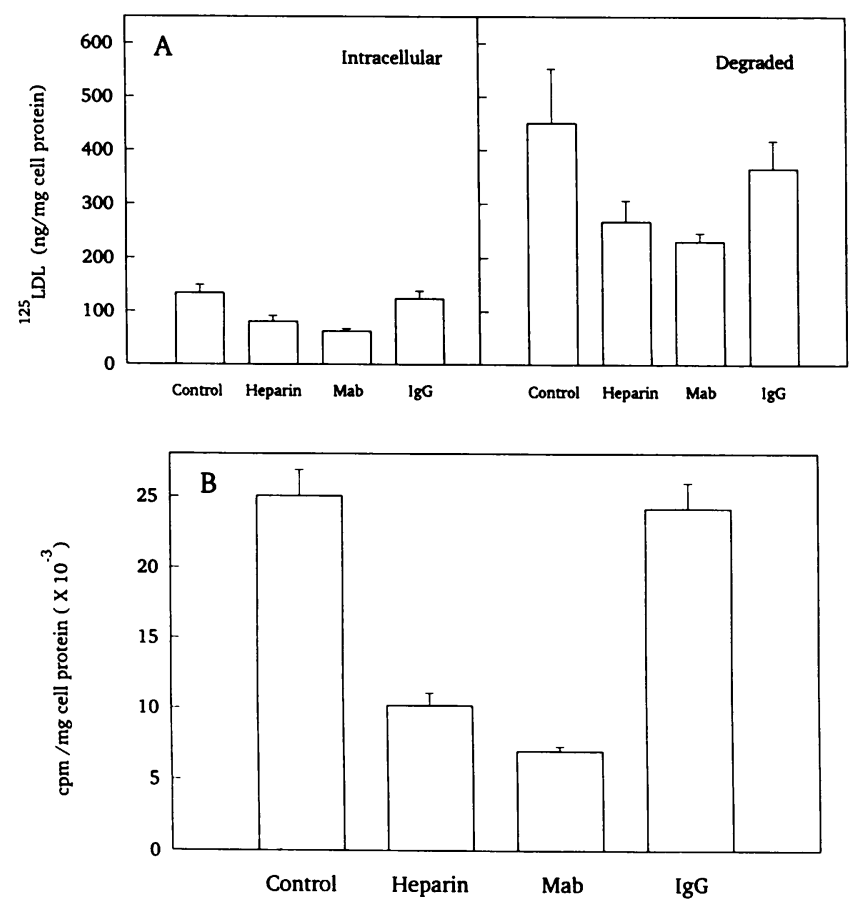

Figure 8. Role of endogenous LPL in lipid particle metabolism by THP-1 macrophages. Cells were incubated for $18 \mathrm{~h}$ as described in Fig. 7 except that no exogenous LPL was added to the incubation. Heparin ( $10 \mathrm{U} / \mathrm{ml})$, anti-LPL monoclonal antibody $(\mathrm{Mab})(100$ $\mu \mathrm{g} / \mathrm{ml})$, or a nonspecific $\mathrm{IgG}(100 \mu \mathrm{g} / \mathrm{ml})$ were added to the cell incubations. $(A)$ Internalized and degraded ${ }^{125}$ I-LDL. $(B)$ Cellular uptake of TG emulsion particles labeled with nondegradable $\left[{ }^{3} \mathrm{H}\right]-$ cholesteryl ether. (Data shown are means \pm SD of triplicate experiments). 
LPL does not aggregate $\operatorname{LDL}(3,25,26)$. Moreover, aggregated LDL is taken up via $L D L$ receptors $(24,27)$. This is not consistent with the slower LPL-mediated pathway demonstrated in our studies, and with our results in receptor negative fibroblasts. Second, our results do not support a role for either LDLrelated protein (LRP) or scavenger receptors. Although LPL may associate with LRP (28) which is present on fibroblasts (29), LRP-mediated uptake of ligands like $\alpha 2$-macroglobulin is much more rapid than LPL-mediated uptake (30). Scavenger receptors are not present at significant levels in either fibroblasts or THP-1 monocytes $(31,10)$. Therefore, neither of these lipoprotein receptors are likely to be involved in LPL-mediated binding, uptake, and degradation of LDL. It is also unlikely that our results were due to lipolysis of LDL by LPL. The binding studies were performed at $4^{\circ} \mathrm{C}$, a temperature at which LPL activity is very low. Furthermore, binding and uptake of TG emulsion particles was independent of TG hydrolysis. Finally, because LPL-mediated effects were blocked by anti-LPL monoclonal antibodies and heparin, it is unlikely that our results were due to a contaminant in the LPL preparation.

LPL-mediated binding, uptake, and degradation of LDL and emulsion particles may require the internalization and degradation of cell surface heparan sulfate proteoglycans. Such a mechanism is illustrated in Fig. 9 and is supported by three observations. (a) Cell surface heparan sulfate proteoglycans are internalized and degraded with a half-life of $\sim 7 \mathrm{~h}$ by pigeon macrophages (32). This time course is compatible with our data for LPL-mediated LDL uptake and degradation. (b) LPL binding to intact heparan sulfate proteoglycans was required for increased LDL binding and increased emulsion uptake. Pretreatment of fibroblasts with heparinase and heparitinase significantly inhibited LPL-mediated LDL uptake. (c) Heparin abrogated LPL-mediated uptake of emulsion particles by fibroblasts, and decreased LDL uptake and degradation by receptor-negative fibroblasts and LPL-secreting macrophages. Furthermore, LPL effects were inhibited by an antibody that blocks LPL-LDL association. These data support our hypothesis that a multimolecular complex, containing LPL and lipidcontaining particles, is internalized and degraded along with cell membrane heparan sulfate proteoglycans.

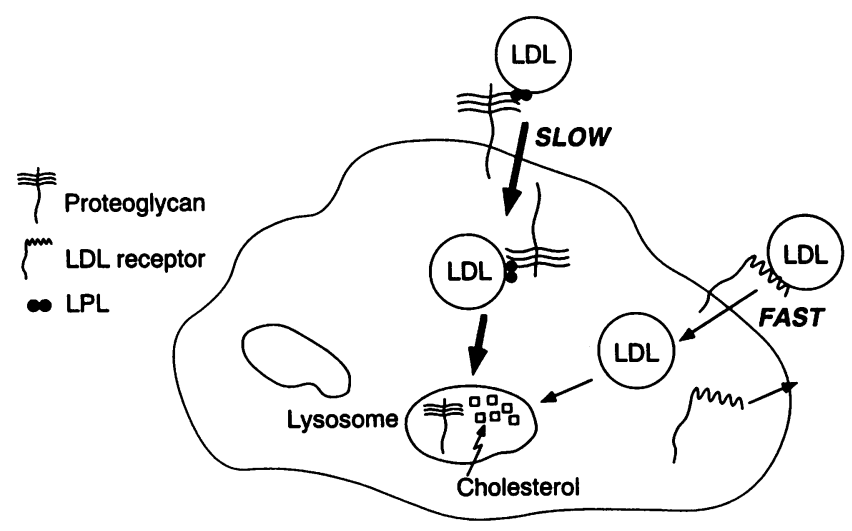

Figure 9. Mechanism for LPL-mediated uptake of LDL. LPL, possessing both heparin and lipid binding domains, can form a bridge between LDL and cell surface heparan sulfate proteoglycans. LDL are internalized together with LPL and the proteoglycans. This is a slower but higher capacity process than uptake via the LDL receptor.
Studies to determine the mechanisms of LPL-mediated LDL uptake were initially performed using fibroblasts; however, the physiological and pathophysiological implications of our studies are most relevant to cells having large amounts of surface LPL. These cells include endothelial cells and LPL synthesizing cells such as adipocytes (4), myocytes (4), hippocampal neurons (33), and macrophages $(34,35)$. We also studied monocytes and macrophages because of their relevance to the generation of atherosclerosis. THP-1 cells synthesize LPL and, therefore, we could study the effect of both endogenously produced LPL and exogenously added LPL on LDL uptake and degradation. As discussed above, uptake and degradation of LDL by these macrophages were inhibited by $(a)$ low concentrations of heparin, which do not dissociate LDL from the LDL receptor but are sufficient to release LPL from the cell surface; and $(b)$ an anti-LPL monoclonal antibody. These data suggest that the ability of THP-1 macrophages to metabolize LDL and lipid emulsions was, to a large degree, dependent on LPL synthesized by these cells.

Although TG-rich lipoproteins are the preferred substrate for LPL-mediated enzymatic actions, LPL associates with both LDL and VLDL. Kinetic studies by Deckelbaum et al. (36) showed that the affinity of LPL for LDL is similar to its affinity for VLDL. Since there are many more molecules of LDL in the circulation of normal individuals, LPL primarily associates with LDL in normolipidemic plasma (25). In addition, because of their greater diameter, VLDL are less likely than LDL to cross the endothelial barrier into the interstitial fluid. Thus, LPL on the surface of vessel wall macrophages would have a greater opportunity to interact with LDL than with VLDL.

The effects of LPL on lipoprotein uptake by macrophages have been reported by other investigators. Lindqvist et al. (37) showed that LPL hydrolytic activity increased VLDL uptake by $\mathbf{J 7 7 4}$ macrophages. Some of this increase was undoubtedly due to interaction of apo $E$ on lipolyzed VLDL with cell surface receptors (38). Using apo CII-deficient VLDL, however, Lindqvist et al. also noted lipolysis independent VLDL uptake. Therefore, some VLDL may have been internalized via the LPL-mediated processes described in our studies. The influence of LPL on LDL uptake by macrophages was studied by Aviram et al. (39). These investigators reported that lipolysis of LDL triglyceride enhanced LDL degradation approximately twofold. Using receptor negative fibroblasts and anti-LDL receptor antibodies, Aviram et al. showed that the uptake of lipolyzed LDL was via the LDL receptor. Thus, the results of Aviram et al. differ from those which we now report both in the magnitude of the effects seen and the mechanism whereby the LPL increased LDL uptake. One major difference between the two studies is that Aviram attempted to remove the LPL from the lipoproteins after the enzymatic hydrolysis. In contrast, in our studies the LPL was present during the interaction of the lipoproteins and cells. The relatively modest effects reported after removal of LPL further support our hypothesis that LPLmediated uptake requires the enzyme to anchor LDL to the cell surface.

Atherosclerotic areas of blood vessels contain more LPL activity than adjacent nondiseased aorta (40). Cholesteryl ester-rich macrophages within the atherosclerotic lesion contain LPL mRNA $(41,42)$; however, the functions of macrophage LPL are unknown. Arterial wall LPL may hydrolyze TG leading to clearance of excess lipid from the subendothelial space. 
Alternatively, as suggested by Zilversmit (40), arterial wall LPL may potentiate the atherosclerotic process by increasing cellular uptake of remnant lipoproteins. Our data suggest that LPL may also increase macrophage LDL uptake, potentiating conversion of macrophages to foam cells. This extrapolation of our vitro studies to the in vivo situation does, however, require several assumptions. Although immunohistological studies have shown LPL in macrophage-rich areas of atherosclerotic lesions, whether the amount of LPL on the surface of these cells is comparable to that on cultured THP-1 macrophages is unknown. Thus, the LPL-mediated uptake of LDL in our studies may be an overestimate, or perhaps an underestimate, of the importance of this pathway in vivo.

LPL-mediated uptake of lipoproteins may be an example of a more generalized phenomenon for lipid uptake not involving lipoprotein receptors. Williams et al. reported that LPL increased uptake of nascent lipoproteins (43) and $L p(a)$ by Hep G2 cells (44). Hepatocytes synthesize a closely related lipase, hepatic triglyceride lipase (HTGL), which is found on the surface of hepatocytes and liver endothelial cells (45). HTGL binds to proteoglycans and lipoproteins $(26,46)$, and may play a role in catabolism of chylomicron and VLDL remnants, as well as high density lipoproteins (47). Recently, Choi et al. showed that HTGL increased LDL uptake by liver cells (48). This may occur via the same mechanism as we have demonstrated for LPL-mediated uptake by fibroblasts and macrophages, namely, a slow but high capacity metabolic pathway. Similarly, pancreatic cholesteryl ester hydrolase augmented lipid uptake by cultured Caco II cells (49), an intestinal-like cell line. Therefore, a number of heparin binding lipases may mediate lipid uptake and metabolism by cells and tissues.

\section{Acknowledgments}

We would like to thank Ms. Anne Gleeson for her help with cell culture.

This work was funded by grants HL-21006 SCOR, HL-45095 and HL-40404 from the National Heart, Blood, and Lung Institute, and a grant from The Council for Tobacco Research-U.S.A., Inc. (No. 2398A). Dr. Goldberg is the recipient of an Established Fellowship for Research from the American Heart Association, New York City Affiliate.

\section{References}

1. Stein, O., G. T. Friedman, T. Chajek-Shaul, G. Halperin, T. Olivecrona and Y. Stein. 1983. Transfer of cholesteryl linoleyl ether from phosphatidylcholine and phosphatidylethanolamine liposomes to cultured cells catalyzed by lipoprotein lipase. Biochim. Biophys. Acta. 750:306-316.

2. Traber, M. G., T. Olivecrona, and H. J. Kayden. 1985. Bovine milk lipoprotein lipase transfers tocopherol to human fibroblasts during triglyceride hydrolysis in vitro. J. Clin. Invest. 75:1729-1734.

3. Saxena, U., M. G. Klein, T. M. Vanni, and I. J. Goldberg. 1992. Lipoprotein lipase increases low density lipoprotein retention by subendothelial cell matrix. J. Clin. Invest. 89:373-380.

4. Eckel, R. H. 1989. Lipoprotein lipase: a multifunctional enzyme relevant to common metabolic diseases. N. Engl. J. Med. 320:1060-1068.

5. Garfinkel, A. S., and M. C. Schotz. Lipoprotein lipase. In Plasma Lipoproteins. A. M. Gotto, Jr., editor. Elsevier Science Publishing Co., New York. 335357.

6. Granot, E., Y. A. Carpentier, I. Tabas, T. Vogel, M. Gorecki, and R. J. Deckelbaum. Cell uptake of small triglyceride-rich particles without apoprotein E is substantial. 1991. Circulation 84(Suppl. II):458.

7. Hussain, M. M., R. W. Mahley, J. K. Boyles, M. Fainaru, and W. J. Brecht. 1989. Chylomicron-chylomicron remnant clearance by liver and bone marrow in rabbits. J. Biol. Chem. 246:9571-9582.
8. Cheng, C. F., G. M. Oosta, A. Bensadoun, and R. D. Rosenberg. 1981. Binding of lipoprotein lipase to endothelial cells in vitro. J. Biol. Chem. 256:12893-12898.

9. Cupp, M., A. Bensadoun, and K. Melford. 1987. Heparin decreases the degradation rate of lipoprotein lipase in adipocytes. J. Biol. Chem. 262:63836388.

10. Auwerx, J. 1991. The human leukemia cell line, THP-1: a multifacetted model for the study of monocyte-macrophage differentiation. Experientia ( $\mathrm{Ba}$ sel). 47:22-30.

11. Auwerx, J. H., S. Deeb, J. D. Brunzell, R. Peng, and A. Chait. 1988. Transcriptional activation of the lipoprotein lipase and apolipoprotein $\mathrm{E}$ genes accompanies differentiation in some human macrophage-like cell lines. Biochemistry. 27:2651-2655.

12. Goldstein, J. L., S. K. Bau, and M. S. Brown. 1983. Receptor-mediated endocytosis of low-density lipoprotein in cultured cells. Methods Enzymol. 98:241-260.

13. Havel, R. J., H. A. Eder, and J. H. Bragdon. 1955. The distribution and chemical composition of ultracentrifugally separated lipoproteins in human serum. J. Clin. Invest. 34:1345-1353.

14. Bilheimer, D. W., S. Eisenberg, and R. I. Levy. 1972. The metabolism of very low density lipoprotein proteins. Preliminary in vitro and in vivo observations. Biochim. Biophys. Acta. 260:212-218.

15. Socorro, L., C. C. Green, and R. L. Jackson. 1985. Preparation of a homogenous and stable form of bovine milk lipoprotein lipase. Prep. Biochem. 15:133-143.

16. Saxena, U., L. Witte, and I. J. Goldberg. 1989. Release of endothelial cell lipoprotein lipase by plasma lipoproteins and free fatty acids. J. Biol. Chem. 264:4349-4355.

17. Goldberg, I. J., D. A. Handley, T. Vanni, J. R. Paterniti, Jr., and J. A. Cornicelli. 1988. Membrane bound lipoprotein lipase on human monocytederived macrophages: localization by immunocolloidal gold technique. Biochim. Biophys. Acta. 959:200-228.

18. Auwerx, J. H., S. Deeb, J. D. Brunzell, G. Wolfbauer, and A. Chait. 1989. Lipoprotein lipase gene expression in THP-1 cells. Biochemistry. 28:4563-4567.

19. Domin, W. S., A. Chait, and S. S. Deeb. 1991. Transcriptional activation of the lipoprotein lipase gene in macrophages by dexamethasone. Biochemistry. 30:2570-2574.

20. Lowry, O. H., N. J. Rosebrough, A. L. Farr, and R. J. Randall. 1951. Protein measurement with the Folin phenol reagent. J. Biol. Chem. 193:267275.

21. Bartlett, G. R. 1959. Phosphorous assay in column chromatography. $J$. Biol. Chem. 234:466-468.

22. Nilsson-Ehle, P., and M. C. Schotz. 1976. A stable, radioactive substrate emulsion for assay of lipoprotein lipase. J. Lipid Res. 17:536-541.

23. Goldstein, J. L., S. K. Basu, G. Y. Brunschede, and M. S. Brown. 1976. Release of low density lipoprotein from its cell surface receptor by sulfated glycosaminoglycans. Cell. 7:85-95.

24. Suits, A. G., A. Chait, M. Aviram, and J. W. Heinecke. 1989. Phagocytosis of aggregated lipoprotein by macrophages: low density lipoprotein receptor-dependent foam cell formation. Proc. Natl. Acad. Sci. USA. 86:2713-2717.

25. Goldberg, I. J., J. J. Kandel, C. B. Blum, and H. N. Ginsberg. 1986. Association of plasma lipoproteins with postheparin plasma lipase activities. $J$. Clin. Invest. 78:1523-1528.

26. Jackson, R. L., L. Socorro, G. M. Fletcher, and A. D. Cardin. 1985. Heparin binding to lipoprotein lipase and low density lipoproteins. FEBS (Fed. Eur. Biochem. Soc.) Lett. 190:297-300.

27. Khoo, J. C., E. Miller, P. Mcloughlin, and D. Steinberg. 1988. Enhanced macrophage uptake of low density lipoprotein after self aggregation. Arteriosclerosis. 8:348-358.

28. Beisiegel, U., W. Weber, and G. Bengtsson-Olivecrona. 1991. Lipoprotein lipase enhances the binding of chylomicrons to low density lipoprotein receptorrelated protein. Proc. Natl. Acad. Sci. USA. 88:8342-8346.

29. Brown, M. S., J. Herz, R. C. Kowal, and J. L. Goldstein. 1991. The LDL receptor-related protein (LRP): double agent or decoy? Curr. Opin. Lipidol. 2:65-72.

30. Tabas, I. A., S. Lim, X. Xu, and F. R. Maxfield. 1990. Endocytosed $\beta$-VLDL and LDL are delivered to different intracellular vesicles in mouse peritoneal macrophages. J. Cell Biol. 111:929-940.

31. Kurihara, Y., A. Matsumoto, H. Itakura, and T. Kodama. 1991. Macrophage scavenger receptors. Curr. Opin. Lipidol. 2:295-300.

32. Owens, R. T., and W. D. Wagner. 1991. Metabolism and turnover of cell surface-associated heparan sulfate proteoglcyan and chrondroitin sulfate proteoglycan in normal and cholesterol-enriched macrophages. Arteriosclosis Thromb. 11:1752-1758.

33. Goldberg, I. J., D. R. Soprano, M. L. Wyatt, T. M. Vanni, T. G. Kirchgessner, and M. C. Schotz. 1989. Localization of lipoprotein lipase mRNA in rat tissues. J. Lipid Res. 30:1569-1577.

34. Khoo, J. C., E. Mahoney, and J. L. Witztum. 1981. Secretion of lipoprotein lipase by macrophages in culture. J. Biol. Chem. 256:7105-7108. 
35. Chait, A., P. H. Iverius, and J. D. Brunzell. 1982. Lipoprotein lipase secretion by human monocyte-derived macrophages. J. Clin. Invest. 69:490-493.

36. Deckelbaum, R. J., S. Eisenberg, E. Levy, T. Olivecrona, and G. Bengtsson-Olivecrona. 1984. Triglyceride hydrolysis in triglyceride vs cholesterol esterrich lipoproteins. Lipoprotein vs hepatic lipase. Arteriosclerosis. 4:563a.

37. Lindqvist, P., A.-M. Ostlund-Lindqvist, J. L. Witztum, D. Steinberg, and J. A. Little. 1983. The role of lipoprotein lipase in the metabolism of triglyceriderich lipoproteins by macrophages. J. Biol. Chem. 258:9086-9092.

38. Huff, M. W., A. J. Evens, B. M. Wolfe, and C. G. Sawyez. 1991. Cholesterol ester and triglyceride accumulation in $\mathrm{J} 774$ macrophages induced by hypertriglyceridemic VLDL occurs by different mechanisms. Arteriosclerosis Thromb. 11:1473a. (Abstr.).

39. Aviram, M., E. L. Bierman, and A. Chait. 1988. Modification of low density lipoprotein by lipoprotein lipase or hepatic lipase induces enhances uptake and cholesterol accumulation in cells. J. Biol. Chem. 263:15416-15422.

40. Zilversmit, D. B. 1979. Atherogenesis: a postprandial phenomenon. Circulation. 60:473-485.

41. O'Brien, K., D. Gordon, S. Deeb, M. Ferguson, and A. Chait. 1992. Lipoprotein lipase is synthesized by macrophage-derived foam cells in human coronary atherosclerotic plagues. J. Clin. Invest. 89:1544-1550.

42. Yla-Herttuala, S., B. A. Lipton, M. E. Rosenfeld, I. Goldberg, D. Steinberg, and J. L. Witztum. 1991. Macrophages and smooth muscle cells express lipoprotein lipase in human and rabbit atherosclerotic lesions. Proc. Natl. Acad. Sci. USA. 88:10143-10147.

43. Williams, K. J., K. A. Petrie, R. W. Brocia, and T. L. Swenson. 1991. Lipoprotein lipase modulates net secretory output of apolipoprotein $B$ in vitro. A combined hyperlipidemia. J. Clin. Invest. 88:1300-1306.

44. Williams, K. J., G. M. Fless, K. Petrie, M. L. Snyder, R. W. Brocia, and T. L. Swenson. 1991. Lipoprotein lipase enhances cellular catabolism of lipoprotein(a). Arterosclerosis Thromb. 11:1425a.

45. Kussi, T., E. A. Nikkila, I. Virtanen, and P. K. J. Kennunen. 1979. Localization of the heparin-releasable lipase in situ in the rat liver. Biochem. J. 181:245-246.

46. Jackson, R. L., S. J. Busch, and A. D. Cardin. 1991. Glycosaminoglycans: molecular properties, protein interactions, and role in physiological processes. Physiol. Rev. 71:481-539.

47. Olivecrona, T., and G. Bengtsson-Olivecrona. 1990. Lipoprotein lipase and hepatic lipase. Curr. Opin. Lipidol. 1:222-230.

48. Choi, S., M. Komaromy, J. Chen, and A. Cooper. 1991. Cells that secrete hepatic lipase or Apo E have enhanced LDL but not chylomicron remnant uptake. Arteriosclerosis Thromb. 11:1405a.

49. Bosner, M. S., T. Gulick, D. J. S. Riley, C. A. Spilburg, and L. G. Lange III. 1988. Receptor-like function of heparin in the binding and uptake of neutral lipids. Proc. Natl. Acad. Sci. USA. 85:7438-7442. 